\title{
Quantity and quality of soil organic matter as a sustainability index under different land uses in Eastern Amazon
}

\author{
Diana Signor ${ }^{1 *}$, Magnus Dall'Igna Deon ${ }^{1}$, Plínio Barbosa de Camargo², Carlos Eduardo Pellegrino Cerri ${ }^{3}$
}

${ }^{1}$ Embrapa Semi-Arid, BR 428, km 152 - 56302-970 -

Petrolina, PE - Brazil.

2University of São Paulo/CENA - Isotopic Ecology Lab., Av. Centenário, 303 - 13416-903 - Piracicaba, SP - Brazil.

3University of São Paulo/ESALQ - Depto of Soil Science, Av. Pádua Dias, 11 - 13418-900 - Piracicaba, SP - Brazil.

*Correspondent author <diana.signor@embrapa.br>

Edited by: Leônidas Carrijo Azevedo Melo

Received September 09, 2016

Accepted March 16, 2017

\begin{abstract}
Soil organic matter (SOM), which influences chemical, physical and biological soil attributes, is the main form of $C$ found in the soil which can also be used as a soil sustainability index. The aim of this study was to use the quantity and quality of SOM as an indicator to determine the sustainability of different land uses (native vegetation, secondary vegetation, fruit orchards, horticultural areas, degraded pasture, improved pasture, and fields with annual crops) in the eastern Amazon. Improved pasture had higher soil $\mathrm{C}$ stock than the other land uses and was similar to the native vegetation, and also presented the highest quantity of $C$ in a stable form in the soil (fraction $<53 \mu \mathrm{m}$ ). According to the $\mathrm{C}$ management index, improved pasture is the most similar in use to native vegetation. Changes in land use reduced the soil microbial $\mathrm{C}$ content, although the more conservationist systems (fruit orchards, secondary vegetation, and improved pasture) had contents similar to those of the native vegetation. The highest soil microbial quotients were found in fruit orchards and horticultural areas. Well-managed pastures were effective in accumulating $\mathrm{C}$ as stable forms in the soil, which demonstrates the sustainability of this land use in the region studied.
\end{abstract}

Keywords: C stocks, changes in land use, physical fractionation, carbon management index, microbial biomass

\section{Introduction}

Soil organic matter (SOM) is the main form of $\mathrm{C}$ found in the soil (Brady and Weil, 2008) and can influence chemical, physical and biological soil attributes, be a source of $\mathrm{C}$ and energy for microorganisms and affect greenhouse gas emissions (Batjes and Sombroek, 1997). SOM is a mixture of molecules from plants, animals and microorganisms (Simpson et al., 2002) with different compositions, levels of availability, and functions in the environment (Carter, 2001).

Physical disturbance of the soil breaks the dynamic equilibrium of the soil causing emission of $\mathrm{CO}_{2}$ into the atmosphere (Paustian et al., 2000). In the Amazon in Brazil, deforestation makes way for the establishment of pastures and recently, grazing areas have been replaced by corn and soybean fields (Frazão et al., 2010; Lammel et al., 2015). This can reduce the $C$ in the $0-20 \mathrm{~cm}$ soil layer by $10 \%$, while changing from agriculture to pasture the soil C content may increase by $26 \%$ (Don, 2011), and achieve a level similar to the native areas (Frazão et al., 2010; Maia et al., 2009). SOM is an important indicator of soil quality and agricultural sustainability, since management practices can cause it to undergo rapid change (Mielnickuk, 2008). Such change can be evaluated using the total soil C content, its chemical and physical fractions or by a combination of these factors (Blair et al., 1997). However, minor changes in total $\mathrm{C}$ content are hard to detect (Blair et al., 1995). Labile C, resulting from soil oxidation with $\mathrm{K}_{2} \mathrm{Cr}_{2} \mathrm{O}_{7}$ at different acidity levels or by physical fractionation of SOM, as well as the microbial biomass can be used as indicators of sustainability for agricultural systems (Araújo and Melo, 2010; Dieckow et al., 2005; Chan et al., 2001).
Blair et al. (1995) proposed the use of labile $\mathrm{C}$ in soil to calculate the $\mathrm{C}$ management index (CMI), which is a measure of the relative sustainability of different systems or land uses in comparison to a reference area, generally a native one (Blair et al., 1997). More conservationist systems and pastures show higher CMI than conventional systems (Schiavo et al., 2011; Silva et al., 2011).

The aim of this study was to use the quality and quantity of SOM as an indicator to determine the sustainability of different land uses in the eastern Amazon.

\section{Materials and Methods}

The study was conducted in rural areas of the municipality of São Luís, in the eastern Amazon in Brazil (geographic coordinates on Table 1). The climate is tropical, hot, and humid, with an average temperature of 32 ${ }^{\circ} \mathrm{C}$ and annual rainfall of $2,326 \mathrm{~mm}$. The rainy season is from Jan to July and the dry season from Aug to Dec. We evaluated areas under different land uses located in the same watershed drainage basin, in a Haplic Ferralsol (FAO-WRB). Land uses evaluated were native vegetation (forest); secondary vegetation (capoeira); improved pasture (represented by a cut and carry grass field); degraded pasture; fruit orchards; horticultural areas; and fields with annual crops (Table 1). The native vegetation represents the original vegetation of that area and was used as the reference site for all comparisons.

Soils samples were collected in Dec 2011. A 300 $\mathrm{m}$-long transect was allocated in each land use. Five points were equidistantly distributed along the transect. At each point along the transect we collected two disturbed soil samples at three layers $(0-10 \mathrm{~cm}, 10-20 \mathrm{~cm}$, 
Table 1 - Coordinates and historical land use of the areas evaluated in São Luís.

\begin{tabular}{|c|c|c|c|c|}
\hline Land use & Coordinates & Elevation & Age / Fertilization & Historical land-use \\
\hline & & $\mathrm{m}$ & & \\
\hline Native vegetation & $\begin{array}{l}02^{\circ} 36^{\prime} 20.8^{\prime \prime} \mathrm{S} \\
44^{\circ} 16^{\prime} 23.6^{\prime \prime} \mathrm{O}\end{array}$ & 24 & - & Preserved area. Same use over the years. \\
\hline Secondary vegetation & $\begin{array}{l}02^{\circ} 36^{\prime} 25.8^{\prime \prime} \mathrm{S} \\
44^{\circ} 15^{\prime} 58.7^{\prime \prime} \mathrm{O}\end{array}$ & 43 & $\begin{array}{c}20 \text { years } \\
\text { No fertilization }\end{array}$ & $\begin{array}{l}\text { Deforested in the } 1970 \text { s for implementation of fruit growing area. It } \\
\text { has been fallow for } 20 \text { years, since the eradication of the orchard. }\end{array}$ \\
\hline Degraded pasture & $\begin{array}{c}02^{\circ} 37^{\prime} 3.1^{\prime \prime} \mathrm{S} \\
44^{\circ} 16^{\prime} 29.5^{\prime \prime} \mathrm{O}\end{array}$ & 26 & $\begin{array}{c}35 \text { years } \\
\text { No fertilization }\end{array}$ & $\begin{array}{l}\text { Converted from native vegetation into pasture. The forage specie } \\
\text { is Brachiaria brizantha cv. Marandu. There is a high level of weed } \\
\text { infestation and many points of uncovered soil. }\end{array}$ \\
\hline
\end{tabular}

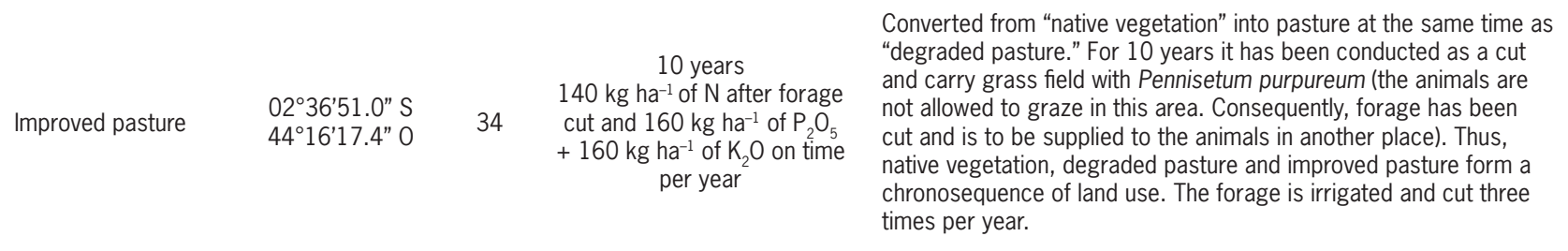

\begin{tabular}{|c|c|c|c|c|}
\hline Annual crops & $\begin{array}{l}02^{\circ} 36^{\prime} 46.0^{\prime \prime} \mathrm{S} \\
44^{\circ} 16^{\prime} 26.2^{\prime \prime} \mathrm{O}\end{array}$ & 45 & $\begin{array}{c}41 \text { years } \\
\text { Fertilization according crop } \\
\text { demand }\end{array}$ & $\begin{array}{l}\text { This area was deforested in } 1970 \text { and since then has been used for } \\
\text { alternative crops such as corn, cowpea beans, rice and cassava, } \\
\text { all under conventional tillage. These crops are cultivated in the rainy } \\
\text { season (Jan to July) and, after the harvest, the area is left fallow during } \\
\text { the dry period of the year (Aug to Dec). }\end{array}$ \\
\hline Fruit trees & $\begin{array}{l}02^{\circ} 36^{\prime} 26.0^{\prime \prime} \mathrm{S} \\
44^{\circ} 16^{\prime} 25.9^{\prime \prime} \mathrm{O}\end{array}$ & 20 & $\begin{array}{l}31 \text { years } \\
\text { Fertilization with manure }\end{array}$ & $\begin{array}{l}\text { This area was deforested in the early } 1980 \text { s for coffee cultivation. In } \\
\text { the same decade, coffee was replaced by fruit trees. At the time of } \\
\text { sampling the species growing in the area were coconut, banana, and } \\
\text { citrus. The area receives sprinkler irrigation during the dry period of } \\
\text { the year. }\end{array}$ \\
\hline Horticulture & $\begin{array}{l}02^{\circ} 36^{\prime} 27.3^{\prime \prime} \mathrm{S} \\
44^{\circ} 15^{\prime} 59.0^{\prime \prime} \mathrm{O}\end{array}$ & 43 & $\begin{array}{l}41 \text { years } \\
\text { Fertilization with manure }\end{array}$ & $\begin{array}{l}\text { Deforested in } 1970 \text { s for the deployment of fruit trees. The area } \\
\text { was kept fallow for } 10 \text { years (secondary vegetation) and then it was } \\
\text { converted into horticulture. The area is irrigated in the dry season } \\
\text { of the year and receives frequent additions of organic amendments. } \\
\text { Thus, there is another chronosequence of land uses: native } \\
\text { vegetation, fruit trees, secondary vegetation, and horticulture. }\end{array}$ \\
\hline
\end{tabular}

and $20-30 \mathrm{~cm})$. The two samples from the same layer were mixed together to form one composite sample per point per layer. These samples were used for chemical and granulometric characterization (Table 2), total C and $\mathrm{N}$, labile $\mathrm{C}$, microbial $\mathrm{C}$ determinations and for the physical fractionation of SOM. A soil trench was opened at the midpoint of each transect and two undisturbed samples were collected for soil density determination.

$\mathrm{C}$ and $\mathrm{N}$ contents were determined by dry combustion. $\mathrm{C}$ and $\mathrm{N}$ stocks $\left(\mathrm{Mg} \mathrm{ha}^{-1}\right)$ were calculated by multiplying the content $(\%)$ of each element in each soil layer, the width of the soil layer $(\mathrm{cm})$, and the soil layer density $\left(\mathrm{g} \mathrm{cm}^{-3}\right)$. C and $\mathrm{N}$ stocks in the deepest layer were corrected by equivalent soil mass (Ellert and Bettany, 1995) using the native vegetation as reference. $\mathrm{C}$ and $\mathrm{N}$ stocks in the $0-30 \mathrm{~cm}$ layer were obtained by the summing the stocks in the $0-10 \mathrm{~cm}, 10-20 \mathrm{~cm}$ and $20-30 \mathrm{~cm}$ layers.

Labile $\mathrm{C}$ concentrations were determined by oxidation with $\mathrm{KMnO}_{4}\left(333 \mathrm{mmol} \mathrm{L}^{-1}\right)+12 \mathrm{~N} \mathrm{H}_{2} \mathrm{SO}_{4}$, according to Chan et al. (2001). Non-labile C was obtained by subtracting labile $\mathrm{C}$ from total $\mathrm{C}$ (dry combustion).
To physically fractionate SOM, $20 \mathrm{~g}$ of air-dried soil and $70 \mathrm{~mL}$ of water were dispersed for $15 \mathrm{~min}$ in an ultrasonic apparatus working at $70 \%$ power $(500 \mathrm{~W})$, providing approximately $13 \mathrm{~J}$ of energy to samples. SOM fractions were separated by wet sieving (Christensen, 1992) into two size classes: 53 to $2000 \mu \mathrm{m}$ (subdivided into organic fraction and mineral fraction by water flotation); and $<53 \mu \mathrm{m}$. Fractions were dried in a circulating air oven $\left(45^{\circ} \mathrm{C}\right)$, weighed, and ground in a porcelain mortar. $\mathrm{C}$ contents in the fractions were determined by dry combustion. The total soil $\mathrm{C}$ stored in each fraction $\left(\mathrm{g} \mathrm{kg}^{-1}\right.$ of soil) was calculated from the mass (g fraction $\mathrm{kg}^{-1}$ of soil) and the $\mathrm{C}$ content in each fraction ( $\mathrm{g} \mathrm{C} \mathrm{kg}^{-1}$ of fraction).

CMI was calculated as follows: $\mathrm{CMI}=\mathrm{C}$ Pool In$\operatorname{dex}(\mathrm{CPI}) \times$ Lability Index $(\mathrm{LI}) \times 100$. In this calculation, $\mathrm{CPI}=\mathrm{C}$ pool in the sample $\left(\mathrm{g} \mathrm{kg}^{-1}\right) / \mathrm{C}$ pool in the reference $\left(\mathrm{g} \mathrm{kg}^{-1}\right) ; \mathrm{LI}=$ lability in the sample $\left(\mathrm{L}_{\mathrm{s}}\right) /$ lability in the reference $\left(\mathrm{L}_{\text {ref }}\right) ; \mathrm{L}=$ content of labile $\mathrm{C} /$ content of non-labile C (Blair et al., 1995). CMI was calculated in two different ways: (i) considering labile $\mathrm{C}$ as the fraction oxidized by slightly acidic $\mathrm{K}_{2} \mathrm{Cr}_{2} \mathrm{O}_{7}$ (Chan et 
Table 2 - Granulometric and chemical characterization of soils under different land uses in São Luís, MA, Brazil (mean \pm standard error of the mean) ( $n=5)$.

\begin{tabular}{|c|c|c|c|c|c|c|c|c|c|c|c|}
\hline $\begin{array}{l}\text { Soil } \\
\text { layer }\end{array}$ & Sand & Silt & Clay & $\mathrm{pH}$ (water) & $P$ & K & $\mathrm{Na}$ & $\mathrm{Ca}$ & $\mathrm{Mg}$ & $\mathrm{Al}$ & $\mathrm{H}+\mathrm{Al}$ \\
\hline $\mathrm{cm}$ & & $\mathrm{g} \mathrm{kg}^{-1}$ & & & $\mathrm{mg} d$ & $\mathrm{cmol}_{\mathrm{c}} \mathrm{dm}^{-3}$ & & & & & \\
\hline \multicolumn{12}{|c|}{ Native vegetation } \\
\hline-10 & $84.6 \pm 11.7$ & $34.4 \pm 5.2$ & $81.0 \pm 9.4$ & $4.5 \pm 0.03$ & $3.3 \pm 1.7$ & $0.06 \pm 0.017$ & $0.06 \pm 0.010$ & $0.5 \pm 0.1$ & $0.8 \pm 0.08$ & $1.6 \pm 0.04$ & 13.1 \\
\hline $0-20$ & $862.2 \pm 19.9$ & $32.0 \pm 2.3$ & $105.8 \pm 21.6$ & & $5.5 \pm 3.4$ & $0.03 \pm$ & $0.04 \pm$ & & & & \\
\hline $0-30$ & $861.0 \pm$ & $28.8 \pm 4.8$ & $110.6=$ & & $5.3 \pm 3.1$ & $0.02 \pm 0.004$ & $0.04 \pm$ & & 0.8 & $1.3=$ & \\
\hline \multicolumn{12}{|c|}{ Secondary vegetation } \\
\hline 10 & $834.8 \pm 6.3$ & $28.6 \pm$ & $b 13$ & 4.4 & $46.2 \pm 1.0$ & $0.06 \pm 0.007$ & $0.03 \pm$ & 0.5 & 0.2 & 1.3 & 10. \\
\hline $0-20$ & $832.0 \pm$ & $32.0 \pm 2.9$ & 136.0 & & $5.2 \pm 1.9$ & 0.03 & $0.03=$ & & & & \\
\hline $0-30$ & $815.8 \pm 14.6$ & $38.2 \pm 1.0$ & $146.2 \pm$ & $4.5 \pm 0.05$ & $2.8 \pm 0.5$ & $0.03 \pm 0$ & $0.02 \pm$ & 0.4 & $0.6 \pm 0.1$ & $1.3 \pm$ & \\
\hline \multicolumn{12}{|c|}{ Fruit trees } \\
\hline 10 & 2 & 7 & & & 11. & $0.09 \pm 0.01$ & & & & & \\
\hline $0-20$ & $906.4 \pm$ & 28.2 & 65.4 & & 4.2 & 0.0 & $0.03 \pm$ & & $0.8=$ & 0.7 & \\
\hline $20-30$ & 890.8 & 23.8 & 3 & & 2.6 & 0.03 & $0.03 \pm$ & 0.7 & .2 & 0.8 & \\
\hline \multicolumn{12}{|c|}{ Horticulture } \\
\hline 10 & 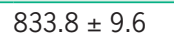 & & & & & & & & & & \\
\hline $0-20$ & $808.4 \pm 8.9$ & $33.6 \pm 3.1$ & $158.4 \pm$ & 0.1 & $43.2 \pm 18.6$ & 0. & $0.03 \pm$ & & & $0.1=$ & \\
\hline $0-30$ & $791.6 \pm 13.0$ & $36.6 \pm 2.5$ & $171.8 \pm 14.8$ & 5.3 & $24.2 \pm 8.5$ & $0.03 \pm 0.005$ & $0.03 \pm$ & 1.0 & 0.9 & 0.5 & \\
\hline \multicolumn{12}{|c|}{ Degraded Pasture } \\
\hline 10 & 866 & .5 & 1 & & 74.5 & $0.03 \pm 0.003$ & 0.02 & & & & \\
\hline $0-20$ & 852. & 32.0 & 115 & $4.7 \pm$ & 51.8 & 0.0 & $0.01 \pm$ & & & & \\
\hline $20-30$ & $826.6 \pm 6.9$ & 30.2 & 143 & 4.6 & $34.3 \pm 1.7$ & $0.01 \pm 0.002$ & $0.01 \pm$ & .1 & 0.6 & 1.1 & 9. \\
\hline \multicolumn{12}{|c|}{ Improved pasture } \\
\hline 10 & 803.6 & .5 & 7 & & 12.6 & $0.07 \pm 0.006$ & 0 & & .05 & 0.2 & 7. \\
\hline $0-20$ & $817.4 \pm 17.1$ & $31.2 \pm 2.8$ & 152.0 & 5.3 & $12.7 \pm 4.4$ & $0.04 \pm 0.004$ & $0.02 \pm$ & $2.0 \pm$ & & $0.2 \pm$ & \\
\hline $20-30$ & $810.6 \pm 13.1$ & $28.4 \pm 4.7$ & $161.0 \pm 16.9$ & $5.3 \pm 0.1$ & $6.2 \pm 1.4$ & $0.03 \pm 0.005$ & $0.01 \pm 0.002$ & $1.3 \pm 0.1$ & $1.3 \pm 0.1$ & $0.4 \pm 0.1$ & $7.5 \pm 0.7$ \\
\hline \multicolumn{12}{|c|}{ Annual crops } \\
\hline-10 & $827.0 \pm 4.8$ & $27.2 \pm 5.1$ & $145.8 \pm 5.2$ & $5.2 \pm 0.1$ & $10.7 \pm 3.2$ & $0.07 \pm 0.008$ & $0.02 \pm 0$ & & $0.9 \pm 0.2$ & $0.2 \pm 0.02$ & $9.5 \pm 0.7$ \\
\hline $10-20$ & $793.4 \pm 5.9 b$ & $26.0 \pm 2.9$ & $181.0 \pm 4.8$ & $5.2 \pm 0.1$ & $9.4 \pm 2.7$ & $0.06 \pm 0.01$ & $0.02 \pm 0.002$ & $1.2 \pm 0.1$ & $0.9 \pm 0.1$ & $0.1 \pm 0.02$ & $8.3 \pm 0.9$ \\
\hline $20-30$ & $775.2 \pm 4.7 b$ & $28.6 \pm 2.0$ & $195.8 \pm 4.9$ & $5.3 \pm 0.1$ & $11.4 \pm 5.0$ & $0.06 \pm 0.02$ & $0.02 \pm 0.004$ & $1.2 \pm 0.2$ & $0.9 \pm 0.2$ & $0.2 \pm 0.03$ & $7.4 \pm 0.8$ \\
\hline
\end{tabular}

al., 2001); and (ii) considering labile C as the SOM fraction with size between 53 and $2000 \mu \mathrm{m}$ (Dieckow et al., 2005; Vieira et al., 2007).

The carbon content of the microbial biomass was determined by the fumigation-extraction method, using 0.38 as the correction factor (Vance et al., 1987). Soil microbial quotient (qMIC) was also calculated according to Anderson and Domsch (1989).

The normal distribution of the data was evaluated by the Shapiro-Wilk test. As normality was not confirmed and the independence assumption was not satisfied, data were subjected to the non-parametric analysis of Kruskal-Wallis and the means were compared by the Bonferroni (Dunn) test. Linear Pearson correlation coefficients (R2) were also calculated for the evaluated parameters. Statistical analyses were carried out using the SAS 9.0 software package.

\section{Results}

The C stock in improved pasture $(0-30 \mathrm{~cm})$ was higher than in any other anthropic use $(50.37 \pm 6.39 \mathrm{Mg}$ $\mathrm{ha}^{-1}$ ) and similar to that in native vegetation (42.63 \pm
$5.10 \mathrm{Mg} \mathrm{ha}^{-1}$ ) (Table 3). Improved pasture also showed the highest $\mathrm{N}$ stock in the $0-30 \mathrm{~cm}$ layer $(3.33 \pm 0.27 \mathrm{Mg}$ $\left.\mathrm{ha}^{-1}\right)$. Accumulated $\mathrm{C}$ and $\mathrm{N}$ stocks in the $0-30 \mathrm{~cm}$ layer were similar to those in the areas under secondary vegetation, fruit orchards, horticulture, degraded pasture and annual crops.

Native vegetation and improved pasture had the highest $\mathrm{C}$ contents in the fraction greater than $53 \mu \mathrm{m}$, reflecting the constant addition of litter in these uses (Table 4 and Figure 1). This fraction contained $19 \%$ of the total $\mathrm{C}$ in native vegetation and $11 \%$ in the other areas (mean of the other land uses evaluated). In all land uses the fraction $<53 \mu \mathrm{m}$ contained most of the soil C: approximately $74 \%$ in native vegetation and $83 \%$ in other uses (Figure 1). In improved pasture, the organic fraction between 53 and $2000 \mu \mathrm{m}$ contained $12 \%$ of the total $\mathrm{C}$ and the fraction $<53 \mu \mathrm{m}$ contained $83 \%$ of the total C.

The greatest contents of labile $\mathrm{C}$ (by physical fractionation) were observed in native vegetation and improved pasture, followed by fruit orchards, while the highest non-labile $\mathrm{C}$ contents occurred in the improved pasture, followed by native vegetation and secondary 
Table 3 - C content, bulk density and C stock in the $0-10 \mathrm{~cm}, 10-20 \mathrm{~cm}$ and $20-30 \mathrm{~cm}$ layers and $\mathrm{C}$ stocks accumulated in the first $30 \mathrm{~cm}$ of depth in soils under different land uses in São Luís, MA, Brazil (mean \pm standard error of the mean). In each land use, lowercase letters compare means on the columns. Means followed by the same letter in the column do not differ as per the Bonferroni test $(\alpha=0.05)$.

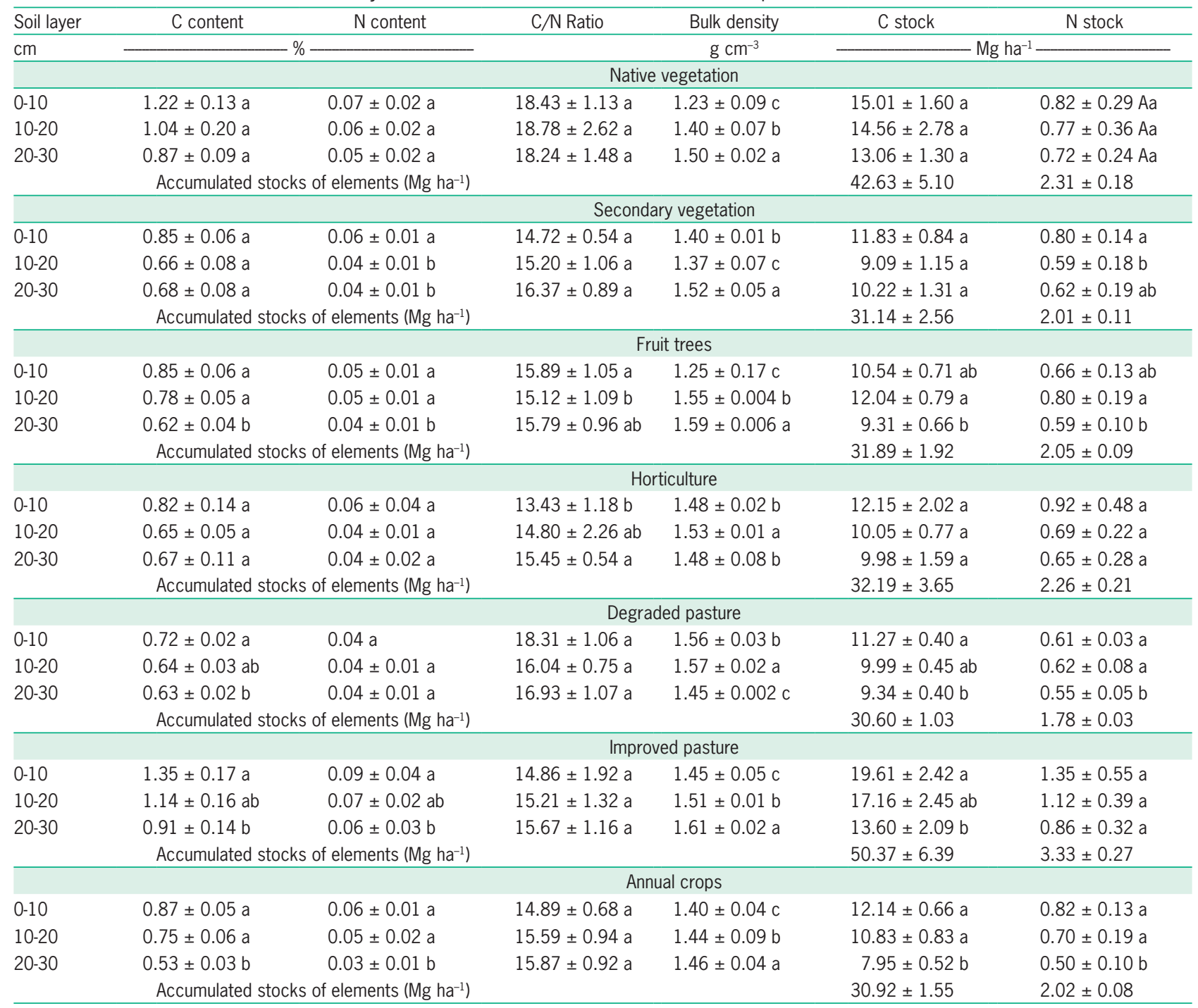

vegetation. In all areas, the CMI calculated by physical fractionation was lower than the reference area value. Improved pasture had the highest CMI in disturbed areas (57.2), followed by fruit orchards (47.5).

The highest values for labile and non-labile $\mathrm{C} \mathrm{ob-}$ tained by oxidation with $\mathrm{K}_{2} \mathrm{Cr}_{2} \mathrm{O}_{7}$ were observed in the improved pasture (Table 5). CMIs in horticultural (97.1) and secondary vegetation (86.2) were close to the reference zone. Using this method, the CMI in improved pasture was $24 \%$ higher than that in native vegetation (Table 5).

Oxidation with $\mathrm{K}_{2} \mathrm{Cr}_{2} \mathrm{O}_{7}$ resulted in higher CMI values when compared to those obtained when using the physical fractionation method (Figure 2). CMI calculated by physical fractionation showed improved pas- ture was the use which gave the result closest to native vegetation, while CMI calculated by $\mathrm{K}_{2} \mathrm{Cr}_{2} \mathrm{O}_{7}$ oxidation surpassed native vegetation. Labile $\mathrm{C}$ obtained by oxidation was positively and moderately correlated to the labile $\mathrm{C}$ content obtained by physical fractionation (R2 $=0.40 ; p=0.02$ ). However, a stronger correlation was observed between the labile $\mathrm{C}$ determined by oxidation and the non-labile $\mathrm{C}$ determined by physical fractionation (R2 $=0.69 ; p<0.01)$.

The $\mathrm{C}$ content of the microbial biomass ranged from 0.056 to $0.181 \mathrm{~g} \mathrm{~kg}^{-1}$ of soil (Table 6). The highest values occurred in orchards and the lowest in annual crops and degraded pasture. The soil microbial quotient ranged from less than $1 \%$ in improved pasture to $3 \%$ at the fruit tree site. 
Table 4 - Total carbon content, Carbon Pool Index (CPI), contents of labile and non-labile C, L (lability), lability index (LI) and carbon management index (CMI) in the 0-10 cm layer (mean \pm standard error of mean) obtained from the physical fractionation of organic matter in soils under different land uses in São Luís, MA, Brazil. Means followed by the same letter in the column do not differ by the Bonferroni test $(\alpha=0.05)$.

\begin{tabular}{|c|c|c|c|c|c|c|c|}
\hline Land use & Total $\mathrm{C}$ content & $\mathrm{CPI}$ & Labile $C^{c}$ & Non-labile $\mathrm{C}^{\mathrm{d}}$ & $\mathrm{Le}^{\mathrm{e}}$ & $\mathrm{Ll}^{\mathrm{f}}$ & $\mathrm{CM} \mathrm{I}^{\mathrm{s}}$ \\
\hline \multicolumn{3}{|c|}{$\mathrm{g} \mathrm{kg}^{-1}$} & \multicolumn{5}{|c|}{$\mathrm{g} \mathrm{kg}^{-1}$} \\
\hline Native vegetation ${ }^{\mathrm{a}}$ & $12.88 \pm 3.33 \mathrm{a}$ & 1.00 & $3.42 \pm 2.41 \mathrm{a}$ & $9.45 \pm 2.21 \mathrm{ab}$ & 0.36 & 1.00 & 100.0 \\
\hline Secondary vegetation & $8.70 \pm 1.77 b$ & 0.67 & $1.45 \pm 0.24 b c$ & $7.25 \pm 1.65 b c$ & 0.20 & 0.56 & 37.5 \\
\hline Fruit trees & $8.46 \pm 1.59 b$ & 0.66 & $1.73 \pm 0.86 a b$ & $6.73 \pm 0.93 c d$ & 0.26 & 0.72 & 47.5 \\
\hline Horticulture & $7.99 \pm 2.95 b c$ & 0.62 & $1.48 \pm 0.67 b c$ & $6.51 \pm 2.31 \mathrm{~cd}$ & 0.23 & 0.64 & 39.7 \\
\hline Degraded pasture & $6.93 \pm 1.07 c$ & 0.54 & $1.12 \pm 0.41 \mathrm{c}$ & $5.80 \pm 0.69 d$ & 0.19 & 0.53 & 28.6 \\
\hline Improved pasture & $13.44 \pm 3.92 \mathrm{a}$ & 1.04 & $2.21 \pm 0.38 \mathrm{a}$ & $11.23 \pm 4.08 \mathrm{a}$ & 0.20 & 0.55 & 57.2 \\
\hline Annual crops & $8.11 \pm 1.31 b c$ & 0.63 & $1.21 \pm 0.42 b c$ & $6.90 \pm 0.96 c$ & 0.17 & 0.47 & 29.6 \\
\hline
\end{tabular}

Reference area for the calculations of $\mathrm{CPI}, \mathrm{LI}$ and $\mathrm{CMI} ;{ }^{\mathrm{b}} \mathrm{CPI}=\mathrm{C}$ pool in treatment $/ \mathrm{C}$ pool in the reference area; clabile $\mathrm{C}=\mathrm{C}$ in labile fractions with size between 53 and $2000 \mu \mathrm{m}$; 'non-labile $\mathrm{C}=\mathrm{C}$ in the labile fraction with size lower than $53 \mu \mathrm{m}$; éability $(\mathrm{L})=$ Labile $\mathrm{C}$ content in the treatment / non-labile $\mathrm{C}$ content in the treatment; 'Lability Index $(\mathrm{LI})=$ lability in the treatment / lability in the reference area; ${ }^{8}$ Carbon Management Index $(\mathrm{CMI})=\mathrm{CPI} \times \mathrm{LI} \times 100$.

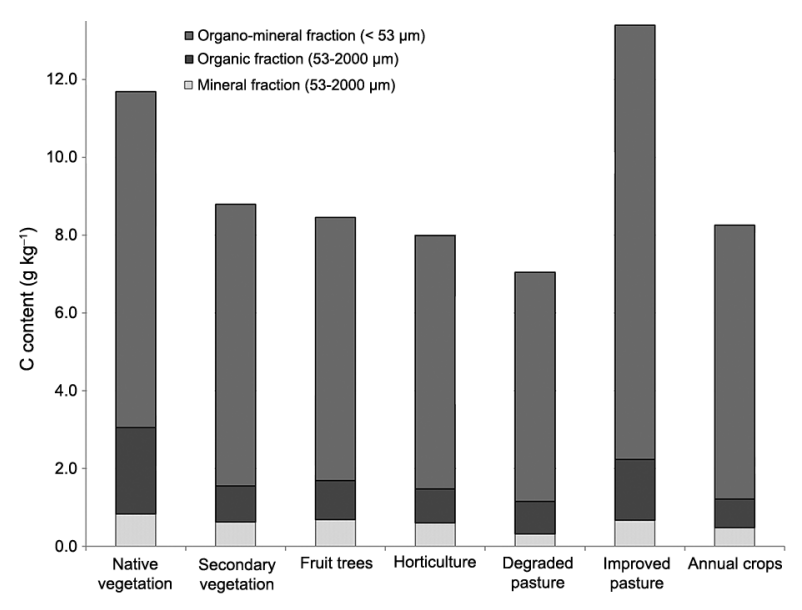

Figure $1-C$ content ( $\mathrm{g} \mathrm{kg}^{-1}$ soil) in physical fractions of soil organic matter $(0-10 \mathrm{~cm})$ obtained by wet sieving in areas under different land uses in São Luís, MA, Brazil.

\section{Discussion}

Native vegetation contains about $42.6 \mathrm{Mg} \mathrm{ha}^{-1}$ of $\mathrm{C}$ in the first $30 \mathrm{~cm}$ (Table 3). In Amazonian soils, the first $30 \mathrm{~cm}$ contains $52 \%$ of $\mathrm{C}$ stored in the first meter (Batjes and Dijkshoorn, 1999). Therefore, the native vegetation area in this study should have had approximately $82 \mathrm{Mg}$ $\mathrm{ha}^{-1}$ of $\mathrm{C}$ in the first meter. The C stock of the first meter of soil in São Luís has been shown to vary between 95 and $115 \mathrm{Mg} \mathrm{ha}^{-1}$ (Batjes and Dijkshoorn, 1999), but our results indicated lower levels.

Considering the first $30 \mathrm{~cm}$ of soil, with the exception of improved pasture, soil C stocks were lower than in the native vegetation. Tillage operations, common after the conversion of native vegetation into other uses, can cause a sizeable loss of soil C (Silva-Olaya et al., 2013). In tropical regions, the conversion of native vegetation into pasture results in the loss of $12 \%$ of soil organic $\mathrm{C}$, mainly due to overgrazing, high export of biomass, and the lack of replenishment of nutrients

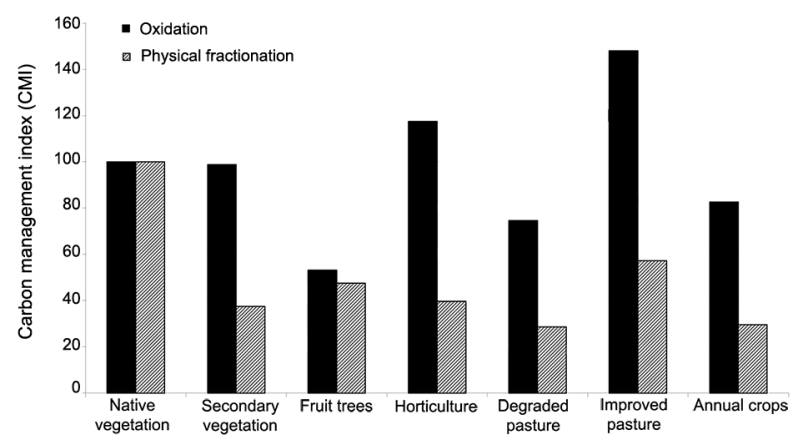

Figure 2 - Comparison between carbon management indexes (CMls) calculated from $\mathrm{C}$ values obtained by oxidation of $\mathrm{C}$ with $\mathrm{K}_{2} \mathrm{Cr}_{2} \mathrm{O}_{7}$ and by physical fractionation of soil organic matter, in 0-10 cm layer, in areas under different land uses in São Luís, MA, Brazil.

(Don, 2011), typical characteristics of poorly managed pastures that will most likely become degraded.

In the Amazon region, degraded pastures can lose about $0.28 \mathrm{Mg} \mathrm{ha}^{-1} \mathrm{yr}^{-1}$ of $\mathrm{C}$, while well-managed pastures with appropriate grazing intensity can have soil $\mathrm{C}$ stocks similar to those in soils under native forest (Maia et al., 2009). In this study, degraded pasture lost approximately $0.34 \mathrm{Mg} \mathrm{ha}^{-1} \mathrm{yr}^{-1}$ of $\mathrm{C}$, while well-managed pasture had a soil $\mathrm{C}$ stock similar to that for soil under native vegetation. However, taking into account that the improved pasture was established after the pasture was allowed to reach a degraded state, this land use accumulated 1.98 $\mathrm{Mg} \mathrm{ha} \mathrm{yr}^{-1}$ of $\mathrm{C}$ and $0.15 \mathrm{Mg} \mathrm{ha}^{-1} \mathrm{yr}^{-1}$ of $\mathrm{N}$. These observations confirm the results of Carvalho et al. (2010), working with different land uses in Brazil, and state that it is soil management which determines whether the conversion from native vegetation to other uses will be a source or a drain of carbon. These authors also observed that non-degraded pastures can accumulate $0.46 \mathrm{~g} \mathrm{ha}^{-1}$ $\mathrm{yr}^{-1}$ of $\mathrm{C}$ in the soil. In the Amazon region, $\mathrm{C}$ sequestration in well-managed pastures can reach $0.61 \mathrm{Mg} \mathrm{ha}^{-1} \mathrm{yr}^{-1}$ due to the influence of the forage root system (Maia et al., 2009; Don, 2011), since nitrogen fertilization (common in 
Table 5 - Total carbon content ( $\mathrm{g} \mathrm{kg}^{-1}$ ), carbon pool index (CPI), levels of labile and non-labile carbon ( $\mathrm{g} \mathrm{kg}^{-1}$ ), L (lability), lability index (LI) and carbon management index (CMI) in the layer 0-10 cm (mean \pm standard error of the mean) obtained by oxidation of $\mathrm{C}$ with $\mathrm{K}_{2} \mathrm{Cr}_{2} \mathrm{O}_{7}$ in soils under different land uses in São Luís, MA. Brazil. Means followed by equal letters in the column do not differ by Bonferroni test $(\alpha=0.05)$.

\begin{tabular}{|c|c|c|c|c|c|c|c|}
\hline Land use & Total $\mathrm{C}$ content & $\mathrm{CPl}$ & Labile C & Non-labile & $\mathrm{L}^{c}$ & $\mathrm{LI}^{\mathrm{d}}$ & CMle \\
\hline & $\mathrm{g} \mathrm{kg}^{-1}$ & & g & - & & & \\
\hline Native vegetation ${ }^{a}$ & $12.21 \pm 1.30 \mathrm{a}$ & 1.00 & $5.74 \pm 1.47 a b$ & $6.47 \pm 1.30 a b$ & 0.89 & 1.00 & 100.00 \\
\hline Secondary vegetation & $8.47 \pm 0.60 b$ & 0.69 & $4.46 \pm 0.58 a b$ & $4.01 \pm 0.28 a b$ & 1.11 & 1.25 & 86.2 \\
\hline Fruit trees & $8.46 \pm 0.57 b$ & 0.69 & $3.42 \pm 0.52 b$ & $5.04 \pm 0.51 \mathrm{ab}$ & 0.68 & 0.76 & 52.4 \\
\hline Horticulture & $8.19 \pm 1.36 b$ & 0.67 & $4.62 \pm 0.37 a b$ & $3.57 \pm 1.10 b$ & 1.29 & 1.45 & 97.1 \\
\hline Degraded pasture & $7.24 \pm 0.26 b$ & 0.59 & $3.25 \pm 0.37 b$ & $4.00 \pm 0.22 b$ & 0.81 & 0.91 & 53.7 \\
\hline Improved pasture & $13.49 \pm 1.67 \mathrm{a}$ & 1.10 & $6.77 \pm 0.83 \mathrm{a}$ & $6.73 \pm 1.07 \mathrm{a}$ & 1.01 & 1.13 & 124.3 \\
\hline Annual crops & $8.66 \pm 0.47 b$ & 0.71 & $4.13 \pm 0.91 b$ & $4.53 \pm 0.63 a b$ & 0.91 & 1.02 & 72.4 \\
\hline
\end{tabular}

aReference area for calculations of $\mathrm{CPI}, \mathrm{LI}$ and $\mathrm{CMl} ;{ }^{\mathrm{b}} \mathrm{C}$ pool in treatment/C pool in the reference area; $\mathrm{C}$ ability $(\mathrm{L})=\mathrm{Labile} \mathrm{C}$ content in the treatment / non-labile $\mathrm{C}$ content in the treatment; 'Lability Index $(\mathrm{LI})=$ lability in the treatment / lability in the reference area; ${ }^{~} \mathrm{Carbon}$ Management Index $(\mathrm{CMI})=\mathrm{CPI} \times \mathrm{LI} \times 100$.

Table 6 - Land uses and levels of microbial $C$ biomass, organic $C$ (mean \pm standard error of the mean) and microbial quotient in the 0-10 cm layer in São Luís, MA, Brazil. Means followed by the same letter in the column do not differ (Bonferroni test, $\alpha=0.05$ ).

\begin{tabular}{llrl}
\hline Land use & \multicolumn{1}{c}{ Microbial C } & Organic C & \multicolumn{1}{c}{$\begin{array}{c}\text { Microbial } \\
\text { quocient (\%) } \\
\text { (microbial C / } \\
\text { organic C) }\end{array}$} \\
\cline { 2 - 4 } Native vegetation & $0.147 \pm 0.026 \mathrm{~b}$ & $10.90 \pm 0.64 \mathrm{a}$ & $1.35 \pm 0.25$ \\
Secondary vegetation & $0.094 \pm 0.017 \mathrm{c}$ & $8.25 \pm 0.36 \mathrm{~b}$ & $1.14 \pm 0.21$ \\
Fruit trees & $0.181 \pm 0.016 \mathrm{a}$ & $5.90 \pm 0.32 \mathrm{c}$ & $3.07 \pm 0.32$ \\
Horticulture & $0.154 \pm 0.010 \mathrm{ab}$ & $7.78 \pm 0.52 \mathrm{~b}$ & $1.98 \pm 0.18$ \\
Degraded pasture & $0.042 \pm 0.067 \mathrm{e}$ & $5.37 \pm 0.25 \mathrm{c}$ & $0.78 \pm 1.25$ \\
Improved pasture & $0.066 \pm 0.007 \mathrm{~cd}$ & $12.40 \pm 0.62 \mathrm{a}$ & $0.53 \pm 0.06$ \\
Annual crops & $0.056 \pm 0.005 \mathrm{de}$ & $7.92 \pm 0.39 \mathrm{~b}$ & $0.71 \pm 0.07$ \\
\hline
\end{tabular}

well-managed pastures) stimulates forage biomass production and leads to the recovery of $\mathrm{C}$ in the soil (Sodhi et al., 2009; Vieira et al., 2007). In the improved pasture in this study, which is used as "a cut and carry grass field", cutting may have stimulated the increase of root density more than grazing (Cunha et al., 2010). Thus, cutting, irrigation and fertilization may explain why the improved pasture showed a higher $\mathrm{C}$ accumulation rate than the well-managed pastures studied by Maia et al. (2009).

The organic fraction between 53 and $2000 \mu \mathrm{m}$ ranged from $9 \%$ (annual crops) to $19 \%$ (native vegetation) of the total $\mathrm{C}$. This fraction consists of recently added material, in the early stages of decomposition, with a short residence time in the soil (Christensen, 2001). Our results confirm that this fraction can undergo rapid change as a result of soil management practices, as observed by Tisdall and Oades (1982), better reflecting such change in the total soil $\mathrm{C}$ content, as noted by Christensen (1992). In all land uses, the amount of $\mathrm{C}$ in the organic fraction between 53 and $2000 \mu \mathrm{m}$ was lower than in the native vegetation (Figure 1). The conversion of native vegetation into degraded pasture reduced the $\mathrm{C}$ in this fraction by $38 \%\left(0.04 \mathrm{~g} \mathrm{~kg}^{-1} \mathrm{yr}^{-1}\right)$, but the improvement of pasture led to the recovery of $\mathrm{C}$ in this fraction $10.07 \mathrm{~g} \mathrm{~kg}^{-1}$ $\left.\mathrm{yr}^{-1}\right)$. Even though this fraction has been rapidly lost due to the change in land use, it was quickly recovered after improved pasture was introduced.

Changing the land use from native vegetation to fruit orchards reduced the $\mathrm{C}$ content in the fraction $53-2000 \mu \mathrm{m}$ to about $45 \%$ of the original content (approximately $0.04 \mathrm{~g} \mathrm{~kg}^{-1} \mathrm{yr}^{-1}$ ). When the fruit orchard was converted to secondary vegetation, $\mathrm{C}$ content was reduced to $42 \%$ (loss rate $0.004 \mathrm{~g} \mathrm{~kg}^{-1} \mathrm{yr}^{-1}$ ), while subsequent horticultural use reduced it to $40 \%$ of the original content (loss rate $0.0045 \mathrm{~g} \mathrm{~kg}^{-1} \mathrm{yr}^{-1}$ ). In this case, soil C losses due to soil tillage may have been minimized by the frequent addition of organic compounds in orchards and horticultural areas.

In the fraction $<53 \mu \mathrm{m}$ the percentage ranged from $74 \%$ to $85 \%$ of total C (Figure 1). This fraction usually makes up 30-70 \% of total C in tropical soils and contains the primary organomineral complexes with high residence time in the soil, which are physically protected against decomposition due to stable bonds formed with soil minerals (Christensen, 2001). Even though native vegetation had the lowest percentage of the total soil $\mathrm{C}$ content in this fraction, this land use has the second largest absolute amount of $\mathrm{C}$ in the fraction $<53 \mu \mathrm{m}$. However, since the native vegetation had the largest absolute $\mathrm{C}$ content in the organic fraction between 53 and $2000 \mu \mathrm{m}$, this fraction has a greater relative importance than in other areas, reducing the percentage of the total $\mathrm{C}$ stored in the fraction $<53 \mu \mathrm{m}$.

In anthropic uses, $\mathrm{C}$ content in the $<53 \mu \mathrm{m}$ fraction was between $70 \%$ and $85 \%$ of that in the native vegetation. The exception was improved pasture, where there was an increase of $29 \%$ (0.53 $\mathrm{g} \mathrm{kg}^{-1} \mathrm{yr}^{-1}$ of C) in the $\mathrm{C}$ content in this fraction after the conversion from degraded pasture. This area is subject to frequent irrigation and fertilization with a regular input of crop residues, but there is no tillage, and the temperature is constant throughout the year, which may have supported microbial activity (Brady and Weil, 2008) and thus 
the transformation of particulate SOM into smaller and more stable complexes (Christensen, 2001).

Because of this, improved pasture also had CPI and CMI values similar to or greater than the native vegetation, and should be considered sustainable as it is maintaining $\mathrm{C}$ in the system (Blair et al., 1995). Therefore, our results indicate well-managed pastures in this region, with adequate nutritional and water management, can increase the amount of $\mathrm{C}$ stored in the soil, confirming previous results (Moraes et al., 2002; Silva Junior et al., 2009; Maia et al., 2010), and can also improve the $\mathrm{C}$ quality in the system.

The chemical method for the determination of labile $\mathrm{C}$ resulted in higher CMI values than the physical SOM fractionation (Figure 2). Physical fractionation separates the organic material not bound to minerals, while chemical fractionation with $\mathrm{K}_{2} \mathrm{Cr}_{2} \mathrm{O}_{7}$ can also attack the organic fraction weakly bound to minerals, overestimating the amount of labile $\mathrm{C}$ and consequently the CMI (Vieira et al., 2007). This explains why the correlation between the labile $\mathrm{C}$ by oxidation and the non-labile $\mathrm{C}$ obtained by physical fractionation was stronger than the correlation obtained where labile $\mathrm{C}$ had been acquired by physical fractionation. As indicated by Vieira et al. (2007), the CMI calculated from the light SOM fraction is more accurate than CMI calculated by oxidation with $\mathrm{K}_{2} \mathrm{Cr}_{2} \mathrm{O}_{7}$.

Microbial $\mathrm{C}$ content in the soil under native vegetation (147 mg kg-1) was similar to that observed by Frazão et al. (2010) in another sandy soil from the Amazon in Brazil (101.4 mg C kg-1 soil). Soils under native vegetation usually have greater $\mathrm{C}$ contents than soils from agricultural areas due to the continuous and diversified supply of organic matter, which is responsible for the structure and development of the microbial community (Frazão et al., 2010; Lammel et al., 2015).

In this study, irrigation and the input of organic fertilizers resulted in high levels of microbial $\mathrm{C}$ in fruit orchards and horticultural sites (Table 6), with irrigation minimizes the effect of the dry season on soil microbial biomass. According to Lou et al. (2011), areas receiving manure have high soil microbial biomass.

The lowest microbial quotients were observed in annual crops and pastures. This indicates that microbial biomass is under stress, possibly due to the quality and/ or quantity of available crop residues. The addition of low-quality waste (higher $\mathrm{C} / \mathrm{N}$ ratio) is responsible for the weak relationship between microbial $\mathrm{C}$ and total organic C, i.e. soil microbial quotient (Deng et al., 2016). The forage $\mathrm{C} / \mathrm{N}$ ratio in improved pasture was 39 and in degraded pastures it was 30 , which may have limited microbial growth and explains the observed microbial quotient.

Converting native vegetation into agricultural areas or pastures reduced the amount of $\mathrm{C}$ immobilized by microorganisms. However, cultivation systems with large inputs of organic material and irrigation, with low- or no-tillage had microbial $\mathrm{C}$ contents similar to the native vegetation. This alone is not enough to indicate that these land uses are superior to native vegetation, because this performance is due to management practices, the use of external $\mathrm{C}$ sources, and its implementation in a relatively small area. Its sustainability must be evaluated in the long term and obviously other variables should be taken into account.

In addition to encouraging $\mathrm{C}$ accumulation in soil, well-managed pastures can be productive for up to 35 years (Cerri et al., 2007) and the recovery of degraded areas improves water quality, plant biomass production and reduces the amount of $\mathrm{CO}_{2}$ emissions into the atmosphere (Lal, 2008). This also has environmental and economic benefits as the capacity for animal stock and greater meat production in that area will be higher. Therefore, the recovery or restoration of grasslands in the Amazon region is a sustainable strategy for increasing soil C stocks. Such practices should be encouraged and disseminated, and will contribute to reduce the pressure for deforestation in areas covered with native vegetation, especially in the Amazon region.

\section{Conclusions}

In the region under evaluation, the conversion of native vegetation to other land uses reduced the $\mathrm{C}$ stored in the soil. However, well-managed pastures have the potential to accumulate $\mathrm{C}$ in the soil in larger amounts than in native areas. Furthermore, the quality of soil $\mathrm{C}$ accumulated in these pastures is better than in degraded pastures or in agricultural areas. Therefore, refurbishment and renovation of pastures in this region are viable alternatives for increasing the capacity for animal stock and promoting accumulation of $\mathrm{C}$ in the soil. Such programs should be continually encouraged by government policies in order to reduce the pressure for deforestation of native forests.

\section{Acknowledgments}

To CAPES (Coordination for the Improvement of Higher Level Personnel) for the scholarship to the first author. To the "Federal Institute of Education, Science and Technology of Maranhão" and "Embrapa Cocais" for logistical support and the staff of the Soil Organic Matter Lab. (University of São Paulo/ESALQ) for helping with the analysis.

\section{References}

Anderson, T.H.; Domsch, K.H. 1989. Ratios of microbial biomass carbon to total organic-carbon in arable soils. Soil Biology and Biochemistry 21: 471-479.

Araújo, A.S.F.; Melo, W.J. 2010. Soil microbial biomass in organic farming system. Ciência Rural 40: 2419-2426.

Batjes, N.H.; Dijkshoorn, J.A. 1999. Carbon and nitrogen stocks in the soils of the Amazon region. Geoderma 89: 273-286.

Batjes, N.H.; Sombroek, W.G. 1997. Possibilities for carbon sequestration in tropical and subtropical soils. Global Change Biology 3: 161-173. 
Blair, G.J.; Lefroy, R.D.B.; Lisle, L. 1995. Soil carbon fractions based on their degree of oxidation, and the development of a carbon management index for agricultural systems. Australian Journal of Agriculture Research 46: 1459-1466.

Blair, G.J.; Lefroy, R.D.B.; Singh, B.P.; Till, A.R. 1997. Development and use of a carbon management index to monitor changes in soil C pool size and turnover rate. p. 273-281. In: Cadisch, G.; Giller, K.E., eds. Driven by nature: plant litter quality and decomposition. CAB International, Wallingford, UK.

Brady, N.C.; Weil, R.R. 2008. The nature and properties of soils. 14ed. Pearson-Prentice Hall, Upper Saddle River, NJ, USA.

Carter, M.R. 2001. Organic matter and sustainability. p. 9-22. In: Rees, R.M.; Ball, B.C.; Campbell, C.D.; Watson, C.A., eds. Sustainable management of soil organic matter. $\mathrm{CAB}$ International, Wallingford, UK.

Carvalho, J.L.N.; Raucci, G.S.; Cerri, C.E.P.; Bernoux, M.; Feigl, B.J.; Wruck, F.J.; Cerri, C.C. 2010. Impact of pasture, agriculture and crop-livestock systems on soil C stocks in Brazil. Soil Tillage Research 110: 175-186.

Cerri, C.E.P.; Easter, M.; Paustian, K.; Killian, K.; Coleman, K.; Bernoux, M.; Falloon, P.; Powlson, D.S.; Batjes, N.H.; Milne, E.; Cerri, C.C. 2007. Predicted soil organic carbon stocks and changes in the Brazilian Amazon between 2000 and 2030. Agriculture, Ecosystems and Environment 122: 58-72.

Chan, K.Y.; Bowman, A.; Oates, A. 2001. Oxidizible organic carbon fractions and soil quality changes in an Oxic Paleustalf under different pasture leys. Soil Science 166: 61-67.

Christensen, B.T. 1992. Physical fractionation of soil: organic matter in primary particle size and density separates. Advances in Soil Science 20: 1-90.

Christensen, B.T. 2001. Physical fractionation of soil and structural and functional complexity in organic matter turnover. European Journal of Soil Science 52: 345-353.

Cunha, F.F.; Ramos, M.M.; Alencar, C.A.B.; Martins, C.E.; Cóser, A.C.; Oliveira, R.A. 2010. Root system of six irrigated grasses under different nitrogen fertilization and management. Acta Scientiarum Agronomy 32: 351-357 (in Portuguese, with abstract in English).

Deng, Q.; Cheng, X.; Hui, D.; Zhang, Q.; Li, M.; Zhang, Q. 2016. Soil microbial community and its interaction with soil carbon and nitrogen dynamics following afforestation in central China. Science of the Total Environment 541: 230-237.

Dieckow, J.; Mielniczuk, J.; Knicker, H.; Bayer, C.; Dick, D.P.; KögelKnabner, I. 2005. Carbon and nitrogen stocks in physical fractions of a subtropical Acrisol as influenced by long-term no-till cropping systems and N fertilization. Plant and Soil 268: 319-328.

Don, A.S.J.F.A. 2011. Impact of tropical land-use change on soil organic carbon stocks: a meta-analysis. Global Change Biology 17: 1658-1670.

Ellert, B.H.; Bettany, J.R. 1995. Calculation of organic matter and nutrients stored in soils under contrasting management regimes. Canadian Journal of Soil Science 75: 529-538.

Frazão, L.A.; Piccolo, M.C.; Feigl, B.J.; Cerri, C.C.; Cerri, C.E.P. 2010. Inorganic nitrogen, microbial biomass and microbial activity of a sandy Brazilian Cerrado soil under different land uses. Agriculture, Ecosystems and Environment 135: 161-167.

Lal, R. 2008. Carbon sequestration. Philosophical Transactions of the Royal Society B 363: 815-830.
Lammel, D.R.; Nüsslein, K.; Tsai, S.M.; Cerri, C.C. 2015. Land use, soil and litter chemistry drive bacterial community structures in samples of the rainforest and Cerrado (Brazilian Savannah) biomes in southern Amazonia. European Journal of Soil Biology 66: 32-39.

Lou, Y.; Xu, M.; Wang, W.; Sun, X.; Liang, C. 2011. Soil organic carbon fractions and management index after $20 \mathrm{yr}$ of manure and fertilizer application for greenhouse vegetables. Soil Use Management 27: 163-169.

Maia, S.M.F.; Ogle, S.M.; Cerri, C.E.P.; Cerri, C.C. 2009. Effect of grassland management on soil carbon sequestration in Rondônia and Mato Grosso states, Brazil. Geoderma 149: 84-91.

Maia, S.M.F.; Ogle, S.M.; Cerri, C.E.P.; Cerri, C.C. 2010. Soil organic carbon stock change due to land use activity along the agricultural frontier of the southwestern Amazon, Brazil, between 1970 and 2002. Global Change Biology 16: 2775-2788.

Moraes, J.F.L.; Neill, C.; Volkoff, B.; Cerri, C.C.; Lima, V.C.; Steudler, P.A. 2002. Soil carbon and nitrogen stocks following forest conversion to pasture in the western Brazilian Amazon basin. Acta Scientiarum 24: 13691376.

Paustian, K.; Six, J.; Elliot, E.T.; Hunt, H.W. 2000. Management options for reducing $\mathrm{CO}_{2}$ emissions from agricultural soils. Biogechemistry 48: 147-163.

Schiavo, J.A.; Rosset, J.S.; Pereira, M.G.; Salton, J.C. 2011. Carbon management index and chemical attributes of an Oxisol under different management systems. Pesquisa Agropecuária Brasileira 46: 1332-1338 (in Portuguese, with abstract in English).

Silva, E.F.; Lourente, E.P.R.; Marchetti, M.E.; Mercante, F.M.; Ferreira, A.K.T.; Fujii, G.C. 2011. Labile and recalcitrant fractions of soil organic matter under integrated crop-livestock system. Pesquisa Agropecuária Brasileira 46: 1321-1331 (in Portuguese, with abstract in English).

Silva Júnior, M.L.; Desjardins, T.; Sarrazin, M.; Melo, V.S.; Martins, P.F.S.; Santos, E.R.; Carvalho, C.J.R. 2009. Carbon content in Amazonian Oxisols after forest conversion to pasture. Revista Brasileira de Ciência do Solo 33: 1603-1611.

Silva-Olaya, A.M.; Cerri, C.E.P.; La Scala Jr., N.; Dias, C.T.S.; Cerri, C.C. 2013. Carbon dioxide emissions under different soil tillage systems in mechanically harvested sugarcane. Environmental Research Letters 8: 015014.

Simpson, A.J. 2002. Determining the molecular weight, aggregation, structures and interactions of natural organic matter using diffusion ordered spectroscopy. Magnetic Resonance in Chemistry 40: S72-S82.

Sodhi, G.P.S.; Beri, V.; Benbi, D.K. 2009. Using carbon management index to assess the impact of compost application on changes in soil carbon after ten years of rice-wheat cropping. Communications in Soil Science and Plant Analysis 40: 3491-3502.

Tisdall, J.M.; Oades, J.M. 1982. Organic matter and water-stable aggregates in soils. Journal of Soil Science 33: 141-163.

Vance, E.D.; Brookes, P.C.; Jenkinson, D.S. 1987. An extraction method for measuring soil microbial biomass-C. Soil Biology and Biochemistry 19: 703-707.

Vieira, F.C.B.; Bayer, C.; Zanatta, J.A.; Dieckow, J.; Mielniczuk, J.; He, Z.L. 2007. Carbon management index based on physical fractionation of soil organic matter in an Acrisol under long-term no-till cropping systems. Soil and Tillage Research 96: 195-204. 